\title{
The Role of Perceived Social and Spiritual Support and Depression to Health-Related Quality of Life on Patients with SLE
}

\author{
Suci Nugraha, ${ }^{1,2}$ Elizabeth Kristi Poerwandari, ${ }^{3}$ Dharmayati Utoyo Lubis ${ }^{3}$ \\ ${ }^{1}$ Doctoral Study Program in Psychology, Faculty of Psychology, Universitas Indonesia, Depok, Indonesia, \\ ${ }^{2}$ Department of Psychology, Faculty of Psychology, Universitas Islam Bandung, Bandung, Indonesia \\ ${ }^{3}$ Department of Psychology, Faculty of Psychology, Universitas Indonesia, Depok, Indonesia
}

\begin{abstract}
Belief in the availability of social support (perceived social support) was known to influence depression and healthrelated quality of life in SLE patients. This support becomes a psychological resource when they experience negative emotional states such as depression caused by a chronic illness such as SLE. In people whose lives are influenced by religion, such as in Indonesian culture, belief in God's help (perceived spiritual support) is an important variable that needs to be studied because it is predicted to affect patients' health-related quality of life. This study aims to explain the relationship between perceived social support, spiritual support, and depression to health-related quality of life in a patient with SLE. This cross-sectional study was conducted from March to June 2021 towards 328 SLE patients selected using the convenient sampling technique. Data was collected through forms that are distributed online and offline. The research sample was SLE patients who were members of a lupus community in Indonesia and lived in several cities in Java. The statistical analysis using a structural model (CMIN/df=103, RMSEA=0.103, CFI=0.972, $\mathrm{TLI}=0.963)$. Chi-square value $=201,835(\mathrm{p}=0.000)$ suggested that perceived social support directly affected the level of depression and health-related quality of life on a patient with SLE, while perceived spiritual support affected the health-related quality of life through the mediation of depression, which means that spiritual support affected the quality of life by reducing negative emotions experienced by SLE patients.
\end{abstract}

Keywords: Depression, health-related quality of life, social support, spiritual support, systemic lupus erythematosus

\section{Peran Dukungan Sosial, Spiritual, dan Depresi terhadap Kualitas Hidup Terkait Kesehatan Pasien SLE}

\begin{abstract}
Abstrak
Keyakinan akan ketersediaan dukungan sosial (perceived social support) diketahui memengaruhi depresi dan kualitas hidup terkait kesehatan pada pasien SLE. Dukungan ini diyakini menjadi sumber daya psikologis saat individu berada dalam kondisi emosi yang negatif seperti depresi yang disebabkan oleh penyakit kronis seperti SLE. Pada masyarakat yang kehidupannya dipengaruhi oleh agama seperti di Indonesia, keyakinan akan pertolongan Tuhan (perceived spiritual support) merupakan variabel penting yang perlu dipelajari karena diprediksi memengaruhi kualitas hidup terkait kesehatan. Penelitian ini bertujuan menjelaskan mekanisme hubungan antara perceived social support, spiritual support, dan depresi terhadap kualitas hidup terkait kesehatan pasien SLE. Penelitian cross-sectional ini dilakukan dari Maret hingga Juni 2021 pada 328 pasien SLE yang dipilih dengan convinient sampling technique. Data dikumpulkan melalui formulir yang disebarkan secara daring dan luring. Sampel penelitian merupakan pasien SLE yang tergabung dalam suatu komunitas lupus dan berdomisili di beberapa kota di pulau Jawa. Hasil analisis statistik dengan model struktural (CMIN/df=103; RMSEA=0,103; CFI=0,972; $\mathrm{TLI}=0,963)$. Nilai chi-square $=201.835(\mathrm{p}=0,000)$ memperlihatkan bahwa perceived social support berpengaruh secara langsung pada tingkat depresi dan kualitas hidup pasien SLE. Sementara itu, perceived spiritual support memengaruhi kualitas hidup terkait kesehatan melalui mediasi depresi yang berarti bahwa spiritual support memengaruhi kualitas hidup dengan mengurangi kondisi emosi negatif yang dirasakan oleh pasien SLE.
\end{abstract}

Kata kunci: Depresi, dukungan sosial, kualitas hidup terkait kesehatan, spiritual support, systemic lupus erythematosus

Received: 31 October 2021; Revised: 22 December 2021; Accepted: 30 December 2021; Published: 31 December 2021 Correspondence: Suci Nugraha, M.Psi., Psikolog. Department of Psychology, Faculty of Medicine, Universitas Islam Bandung. Jln. Tamansari No. 1, Bandung 40116, West Java, Indonesia. E-mail: sucinugraha.psy@gmail.com 


\section{Introduction}

Health-related quality of life is an essential aspect of the health and well-being of a patient with systemic lupus erythematosus (SLE). ${ }^{1}$ According to WHO, quality of life (QoL) is defined as 'individuals' perception of their position in life in the context of culture and value systems in which they live and their goals, expectations, standards, and concerns. ${ }^{2}$ SLE has a very significant impact on patients' quality of life, making them unable to carry out daily activities compared to the healthy population. ${ }^{3}$ Research showed that the quality of life of SLE patients decreased compared to the general population. ${ }^{4}$ In addition, the quality of life of patients with SLE was lower than other chronic diseases, ${ }^{5}$ both in physical and mental dimensions.

SLE patients experience general symptoms that become a burden to their lives, such as fatigue, sleeping difficulty/sleep problems, and pain; hence it is common to experience depression and anxiety. ${ }^{6}$ According to Anyfanti et al., ${ }^{7}$ depression and anxiety were found in $21.8 \%$ to $30.8 \%$ of SLE patients and significantly correlated with health-related quality of life. Therefore, to reduce depression and improve the quality of life of SLE patients, both social and spiritual support is needed.

Religious individuals believe that God or higher power outside of themselves determines the conditions they experience, including health. Therefore, they generally think their illness has a divine purpose. ${ }^{8,9}$ Belief in God is often found in patients with chronic diseases..$^{9,10}$ The direct effect of believing in God is the feeling of closeness with the divine, which, in turn, becomes a resource for individuals to overcome difficult times..$^{11}$ The study about the effect of believing God as a source of mental support for chronic disease patients, especially SLE patients, needs to be conducted towards Indonesian society-which has a religious culture.

Several factors were found to be the resources for SLE patients facing difficult times and closely related to depression and quality of life, including perceived social support. Several findings indicated that low perceived social support was associated with a weakened immune system. ${ }^{12}$ Perceived social support was consistently associated with health through healthy behaviors, more adequate coping strategies, ${ }^{13-15}$ and a better quality of life ${ }^{16}$ It also moderated the relationship between stressful life events and depression. ${ }^{17}$ The perception that family and friends will support during stress was consistently associated with good mental health, including lower rates of major depression..$^{18}$ Perceived spiritual support as a form of perceived social support proved to have an important role when facing traumatic life events over which they have little control. ${ }^{19}$ Maton $^{11}$ argued perceived spiritual support was a predictor of more positive mental health.

The effect of perceived social support on SLE patients' depression and health-related quality of life has been widely investigated. Still, only a few studies investigated the impact of spiritual support on these two variables. The study about the effect of spiritual support on depression and SLE patients' quality of life is still limited. It prompted the authors to investigate the impact of these variables in patients with SLE who deal with high and chronic life stress.

Perceived social support and spiritual support are beliefs about several different sources of support. However, research on the effect of these variables on patients with SLE is still lacking. Therefore, research on the impact of these two types of support towards depression and health-related quality of life in SLE patients will contribute to literature about the effect of support on patients with chronic disease. Specifically, this study examines the impact of perceived social support, spiritual support, and depression on health-related quality of life in patients with SLE.

\section{Methods}

This study was conducted on patients with SLE in the Lupus Indonesia Volunteer (Relawan Lupus Indonesia, ReLI) community. The convenience sampling technique was used. It was one of the non-probability sampling techniques in which the sample was deliberately selected as it was considered the most suitable for research. ${ }^{20}$

The following are the inclusion criteria and exclusion criteria. Inclusion criteria to be respondents are as follows: (1) patients with SLE, (2) in their early and middle adulthood, and (3) SLE disease activity is minimal, at least in the last three months. Exclusion criteria for research subjects include (1) patients with SLE who are experiencing flares or moderate and high disease activity, (2) patients with autoimmune other than SLE.

Four hundred two respondents filled out 
the questionnaire, with 328 were found to meet the criteria for this research. Furthermore, all respondents expressed consent to participate in the study. The Research Ethics Committee, Faculty of Psychology, Universitas Indonesia has approved this research, with the ethics committee approval number: 379/FPsi.Komite Etik/PDP.04.00/2018.

All variables studied used a self-reported questionnaire. ${ }^{19}$ The instruments were provided in person (paper-and-pencil) and online (via google form), starting with informed consent, demographic factors, and questionnaires.

We used the Indonesian version of Lupus QoL to assess the health-related quality of life. Most studies examining SLE patients' healthrelated quality of life use the generic instrument of Medical Outcome Study Short Form (SF-36). The advantage of a generic tool is that it allows comparing the health-related quality of life of patients with SLE with other chronic patients or with a normal population. In addition, generic instruments have been extensively validated and adapted in various languages and cultures. But, the disadvantage of a generic tool is that sensitivity is lacking in detecting a specific symptom of SLE

Lupus QoL measures eight domains of quality of life: physical health, emotional health, body image, pain, planning, fatigue, intimate relationships, and being a burden to others. The questions given were in the form of range using a 5 -point Likert scale ( $\mathrm{O}=$ all the time to $4=$ never). Lupus QoL shows good internal consistency (Cronbach's a ranging from 0.88, 0.87, 0.96, $0.94,0.92,0.90,0.86,0.91)$, respectively.

Multidimensional Perceived Social Support (MPSS) was used to measure belief about the availability of social support. This instrument consists of 12 items which are divided into three subscales in the form of a 7-point Likert scale ( $1=$ strongly disagrees with to $7=$ is strongly agree). MPSS reliability is $0.81,{ }^{21}$ with each subscale measuring perceived support from 3 sources (i.e., family, friends, and significant other). This instrument is a generic instrument widely used in research on social support.

Maton $^{11}$ conceptualized spiritual support similar to perceived social support and divided it into three dimensions: (1) emotional aspects, (2) proximity, and (3) belief. Respondents were asked to answer a 7-point scale to mark whether the items in question were following their situation. The original spiritual support scale consisted of 3 items. Since this instrument was constructed initially for Christian religious tradition, we added 1 item in each dimension to align with Indonesia's religious diversity, bringing six items. The internal consistency value of this scale is 0.95 , while the reliability value is $0.81 .^{22}$ The instrument used was a 7-point Likert scale ( $1=$ strongly disagrees to $7=$ strongly agree). To see the factors in this instrument, the authors conducted a Confirmatory Factor Analysis (CFA) and validity test. The validity test result shows that all items are valid, and this tool has a reliability value of 0.94 .

The Beck Depression Inventory-II, which has been adapted into the Indonesian language, was used to measure depression. This inventory consisting of 21 items measures cognitive, somatic, and affective factors. The Cronbach's $\alpha$ BDI II score for Indonesia is 0.9 for the total score, 0.8 for cognitive factors, 0.81 for somatic factors, and 0.74 for affective factors..$^{23}$ Each item has a measurement scale of $0-3$. A value of o indicates minimal depressive symptoms, while 3 indicates major depressive symptoms. For example, a score of $0-13$ is considered minimal depression, a score of 14-19 is regarded as mild depression, a score of $20-28$ is deemed moderate depression, and a score of 29-63 is considered major depression.

Data analysis was performed using SPSS software version 23.0. The mean, standard deviation, and range of data were used for the continuous and frequency variables, and percentages were used for categorical variables to describe respondents' socio-demographic characteristics.

Data were analyzed to determine the effect of perceived social support, perceived spiritual support, and depression on health-related quality of life. To investigate the relationship between these variables, the Structural Equation Modeling (SEM) test was carried out by using Analysis of Moment Structures (AMOS).

\section{Results}

The demographic characteristics of the respondents in this study are shown in Table 1.

Table 2 shows the results of the statistical analysis. The averagevalue of spiritual support was $39.02(\mathrm{SD}=4.62)$, while the value of depression was $16.77(\mathrm{SD}=9.53)$. The value of health-related quality of life domains which varied between 55- 
Table 1 Demographics

\begin{tabular}{|c|c|c|}
\hline Characteristics & $n=328$ & $\%$ \\
\hline \multicolumn{3}{|l|}{ Occupation } \\
\hline Employed & 143 & 43.6 \\
\hline Housewives & 115 & 35.1 \\
\hline School/college students & 45 & 13.7 \\
\hline Unemployed & 25 & 7.6 \\
\hline \multicolumn{3}{|l|}{ Education } \\
\hline Bachelor's/master's degree & 123 & 37.5 \\
\hline Diploma-3 & 35 & 10.7 \\
\hline Senior high school/ & 153 & 46.6 \\
\hline vocational school & 14 & 4.3 \\
\hline Junior high school & 3 & 0.9 \\
\hline $\begin{array}{l}\text { Others (elementary school, } \\
\text { diploma-1) }\end{array}$ & & \\
\hline \multicolumn{3}{|l|}{ Marital status } \\
\hline Married & 199 & 60.7 \\
\hline Divorced & 15 & 4.6 \\
\hline Widowed & 1 & 0.3 \\
\hline Single & 113 & 34.4 \\
\hline \multicolumn{3}{|l|}{ Children } \\
\hline Have children & 157 & 47.9 \\
\hline Doesn’t have children & 171 & 52.1 \\
\hline \multicolumn{3}{|l|}{ Duration of illness (years) } \\
\hline$\geq 5$ & 115 & 35.1 \\
\hline $3-4$ & 89 & 27.1 \\
\hline $1-2$ & 112 & 34.1 \\
\hline$\leq 1$ & 12 & 3.7 \\
\hline \multicolumn{3}{|l|}{ Comorbidities } \\
\hline Have comorbidities & 140 & 42.7 \\
\hline Doesn’t have comorbidities & 188 & $57 \cdot 3$ \\
\hline \multicolumn{3}{|l|}{ Last relapse } \\
\hline$\geq 3$ years & 35 & 10.7 \\
\hline $2-3$ years & 22 & 6.6 \\
\hline $1-2$ years & 56 & 17.1 \\
\hline $6-12$ months & 118 & 36.0 \\
\hline$<6$ months & 97 & 29.6 \\
\hline \multicolumn{3}{|l|}{ Gender } \\
\hline Male & 17 & 5.2 \\
\hline Female & 311 & 94.8 \\
\hline
\end{tabular}

80. The mean values of the eight domains were as follows: physical domain (65,79), emotion (62.82), body image (66.97), pain (69.74), fatigue (58.12), interpersonal/intimate relationships (81.33), and being a burden to others $(55,16)$.

From the results of the analysis of the final CFA model, we obtained $\chi^{2}=180.9397$ with a probability $\mathrm{p}$ value $=.000$. When compared with the required critical value $\chi^{2}>\chi^{2}$ table $=123,225$ (real level of $5 \%$ and the degrees of freedom $\mathrm{DB}=99$ ) or the real probability value ( $\mathrm{p}$ value)

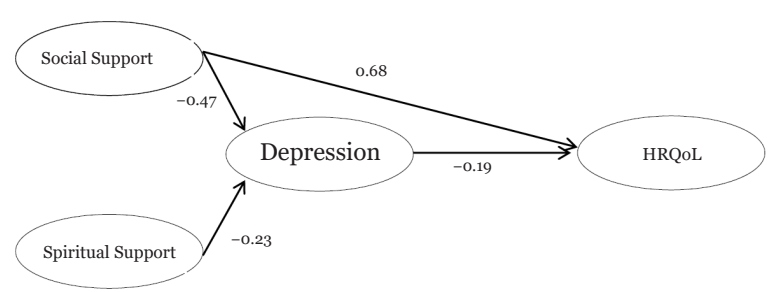

Figure SLE Patients' Structural Model of
Health-Related Quality of Life

below 0.05, thus $\mathrm{H}_{0}$ was rejected. RMSEA of 0.0503 was smaller than 0.08. Likewise, the comparative fit index value, all of which were above 0.90, explained that the model was in the good category with CMIN/DF below 2.00. Thus, this CFA model is considered quite appropriate in forming the constructs that would be used in SEM.

The tests was carried out by using the SEM full model through AMOS showed that the model was good fit at $\mathrm{CMIN} / \mathrm{df}=103$; RMSEA=0.103; $\mathrm{CFI}=0.972 ; \quad \mathrm{TLI}=0.963$. The value of chisquare $=201,835 ; p=0.000$ indicated a fit model.

\section{Discussion}

This study examines the model of effects of perceived social support, spiritual support, and depression towards the health-related quality of life in a patient with SLE. The analysis suggested that all research hypotheses were accepted except for the direct effect of perceived spiritual support on health-related quality of life. Perceived spiritual support indirectly affected the quality of life through the mediation of depression. Research on the impact of perceived social support on quality of life has been widely conducted with consistent results that it will reduce depression and improve quality of life. Data analysis results showed that perceived social support had a more significant direct effect on depression and quality of life than spiritual support. This finding revealed that although perceived social support and spiritual support were beliefs about a source of help, their effects on depression and quality of life were different.

We will first discuss perceived social support on depression and health-related quality of life. This study found a negative impact of perceived social support towards depression. This finding confirmed previous studies in the same population that patients with SLE with high 
Table 2 Results of Data Analysis

\begin{tabular}{|c|c|c|c|c|c|c|c|c|}
\hline \multirow[b]{2}{*}{ Characteristics } & \multicolumn{8}{|c|}{ HRQoL Domain } \\
\hline & $\begin{array}{c}\text { Depression } \\
\text { Mean } \pm \text { SD }\end{array}$ & $\begin{array}{c}\text { Physical } \\
\text { Mean } \pm \text { SD }\end{array}$ & $\begin{array}{l}\text { Emotional } \\
\operatorname{Mean} \pm \text { SD }\end{array}$ & $\begin{array}{c}\text { Body } \\
\text { Image } \\
\text { Mean } \pm \text { SD }\end{array}$ & $\begin{array}{c}\text { Pain } \\
\text { Mean } \pm \text { SD }\end{array}$ & $\begin{array}{c}\text { Fatigue } \\
\text { Mean } \pm \text { SD }\end{array}$ & $\begin{array}{c}\text { Intimate } \\
\text { Relationship } \\
\text { Mean } \pm \text { SD }\end{array}$ & $\begin{array}{c}\text { Burden to } \\
\text { Others } \\
\text { Mean } \pm \text { SD }\end{array}$ \\
\hline Employed & $15.58 \pm 8.14$ & $69.14 \pm 19$ & $66.57 \pm 22.32$ & $70.13 \pm 25$ & $72.9 \pm 22.1$ & $59.44 \pm 22.02$ & $81.99 \pm 22.72$ & $58.56 \pm 29.58$ \\
\hline Housewives & $15.57 \pm 9.87$ & $68.15 \pm 23.03$ & $65.36 \pm 25.28$ & $70.26 \pm 27.87$ & $70 \pm 23.92$ & $61.41 \pm 24.85$ & $74.67 \pm 28.21$ & $59.34 \pm 28.27$ \\
\hline $\begin{array}{l}\text { School/college } \\
\text { students }\end{array}$ & $22.15 \pm 11.37$ & $54.51 \pm 25.17$ & $48.88 \pm 26.58$ & $55.11 \pm 29.72$ & $60 \pm 25 \cdot 35$ & $50.55 \pm 29.37$ & $91.94 \pm 14.63$ & $44.44 \pm 31.88$ \\
\hline Unemployed & $19.44 \pm 8.23$ & $56 \pm 23.47$ & $54.66 \pm 27 \cdot 3$ & $55 \pm 30.75$ & $68 \pm 30.39$ & $49 \pm 23.7$ & $89 \pm 22.62$ & $35.66 \pm 32.05$ \\
\hline \multicolumn{9}{|l|}{ Education } \\
\hline $\begin{array}{l}\text { Bachelor's/master's } \\
\text { degree }\end{array}$ & $15.63 \pm 9.15$ & $65.67 \pm 22.64$ & $63.14 \pm 24.75$ & $67.76 \pm 28.56$ & $66.86 \pm 25.55$ & $58.38 \pm 23.64$ & $79.97 \pm 24.2$ & $56.77 \pm 30.03$ \\
\hline Diploma-3 & $13.59 \pm 7.36$ & $77.95 \pm 15.32$ & $72.29 \pm 20.37$ & $79.32 \pm 22.88$ & $83.55 \pm 14.49$ & $68.75 \pm 21.94$ & $87.83 \pm 17.55$ & $66.89 \pm 21.73$ \\
\hline $\begin{array}{l}\text { Senior high school/ } \\
\text { vocational school }\end{array}$ & $18.45 \pm 9.68$ & $62.47 \pm 22.57$ & $59.99 \pm 25.15$ & $63.3 \pm 26.84$ & $67.97 \pm 24.01$ & $55.02 \pm 24.35$ & $80.47 \pm 26.54$ & $51.14 \pm 32.19$ \\
\hline Junior high school & $16.8 \pm 12.85$ & $70.41 \pm 22.89$ & $65.55 \pm 33.01$ & $67.33 \pm 33.64$ & $77.22 \pm 21.7$ & $61.25 \pm 33.17$ & $85 \pm 20.15$ & $53.88 \pm 27.61$ \\
\hline $\begin{array}{l}\text { Others (elementary } \\
\text { school, diploma-1) }\end{array}$ & $26 \pm 6.24$ & $57.29 \pm 18.04$ & $51.38 \pm 16.83$ & $33.33 \pm 36.85$ & $58.33 \pm 8.33$ & $50 \pm 0$ & $87.5 \pm 12.5$ & $61.11 \pm 37.57$ \\
\hline \multicolumn{9}{|l|}{ Marital status } \\
\hline Married & $15.09 \pm 9.34$ & $69.59 \pm 21.63$ & $68.4 \pm 24.37$ & $71.15^{ \pm 26.64}$ & $70.89 \pm 23.53$ & $61.02 \pm 24.4$ & $77.07 \pm 26.16$ & $62.01 \pm 27.91$ \\
\hline Divorced & $19.56 \pm 6.72$ & $62.5 \pm 18.07$ & $64.06 \pm 20.4$ & $69.68 \pm 24.04$ & $76.56 \pm 14.34$ & $62.89 \pm 18.74$ & $77 \cdot 34 \pm 29.3$ & $46.87 \pm 31.16$ \\
\hline Widowed & $19 \pm 0$ & $84 \cdot 37 \pm 0$ & $58.33 \pm 0$ & $80 \pm 0$ & $91.66 \pm 0$ & $68.75 \pm 0$ & $100 \pm 0$ & $75 \pm 0$ \\
\hline Single & $19.34 \pm 9.53$ & $59.54 \pm 22.78$ & $52.8 \pm 23.96$ & $59.2 \pm 28.64$ & $66.74 \pm 26.05$ & $52.32 \pm 24.6$ & $89.38 \pm 18.39$ & $44.24 \pm 31.4$ \\
\hline \multicolumn{9}{|l|}{ Children } \\
\hline Have children & $14.54 \pm 8.51$ & $70.82 \pm 22.34$ & $69.55 \pm 22.4$ & $74.64 \pm 23.5$ & $72.82 \pm 21.3$ & $62.3 \pm 24.09$ & $77.78 \pm 26.68$ & $63.58 \pm 26.22$ \\
\hline $\begin{array}{l}\text { Doesn't have } \\
\text { children }\end{array}$ & $18.81 \pm 9.97$ & $61.16 \pm 22.34$ & $56.62 \pm 25.87$ & $59.91 \pm 29.46$ & $66.91 \pm 24.15$ & $54.27 \pm 24.38$ & $84.57 \pm 22.04$ & $47.41 \pm 32.03$ \\
\hline \multicolumn{9}{|l|}{$\begin{array}{l}\text { Duration of illness } \\
\text { (years) }\end{array}$} \\
\hline$\geq 5$ & $15.73 \pm 8.54$ & $65.67 \pm 22.93$ & $64.16 \pm 25.78$ & $69.73 \pm 26.28$ & $69.13 \pm 25.67$ & $59.67 \pm 23.18$ & $75.86 \pm 26.63$ & $58.62 \pm 31.58$ \\
\hline $3-4$ & $16.59 \pm 9.72$ & $65.94 \pm 21.76$ & $63.48 \pm 25.79$ & $68.25 \pm 29.74$ & $70.97 \pm 25.25$ & $58.07 \pm 25.05$ & $82.02 \pm 26.71$ & $54.96 \pm 31.57$ \\
\hline $1-2$ & $18.19 \pm 10.25$ & $64.42 \pm 22.73$ & $60.45 \pm 24.3$ & $63.16 \pm 26.84$ & $69.27 \pm 21.97$ & $55 \cdot 97 \pm 25 \cdot 39$ & $84.82 \pm 20.23$ & $50.74 \pm 28.37$ \\
\hline$\leq 1$ & $14.83 \pm 9.63$ & $78.38 \pm 13.87$ & $67.01 \pm 20.9$ & $66.25 \pm 33.44$ & $70.83 \pm 22.89$ & $63.54 \pm 26.35$ & $95.83 \pm 9.73$ & $64.58 \pm 26.38$ \\
\hline \multicolumn{9}{|l|}{ Comorbidities } \\
\hline Have comorbidities & $17.79 \pm 9.08$ & $63.7 \pm 21.83$ & $60.17 \pm 24.67$ & $65.85 \pm 25.94$ & $69.28 \pm 24.44$ & $55.08 \pm 24.25$ & $76.69 \pm 26.1$ & $50.71 \pm 31.07$ \\
\hline $\begin{array}{l}\text { Doesn't have } \\
\text { comorbidities }\end{array}$ & $16.01 \pm 9.8$ & $67.33 \pm 22.65$ & $64.78 \pm 25.27$ & $67.79 \pm 29.04$ & $70.07 \pm 24$ & $60.37 \pm 24.57$ & $84.77 \pm 22.83$ & $58.46 \pm 29.62$ \\
\hline \multicolumn{9}{|l|}{ Last relapse } \\
\hline$\geq 3$ years & $11.45 \pm 7.46$ & $75.08 \pm 21.37$ & $74.16 \pm 24.35$ & $75.85 \pm 26.52$ & $74.52 \pm 23.56$ & $70 \pm 24.1$ & $74.28 \pm 27.77$ & $71.66 \pm 26.82$ \\
\hline $2-3$ years & $16 \pm 10.34$ & $70.59 \pm 23.27$ & $65.53 \pm 26.88$ & $73.18 \pm 25.09$ & $70.45 \pm 27.18$ & $67.61 \pm 22.79$ & $73.29 \pm 33.25$ & $64.77 \pm 28.85$ \\
\hline 1-2 years & $16.82 \pm 10$ & $68.02 \pm 21.88$ & $62.64 \pm 25.63$ & $71.42 \pm 27.04$ & $73.66 \pm 24.91$ & $60.04 \pm 24.09$ & $82.58 \pm 23.91$ & $55.65 \pm 29.39$ \\
\hline 6-12 months & $16.61 \pm 9.64$ & $67.92 \pm 21.37$ & $64.97 \pm 22.81$ & $68.55 \pm 25.52$ & $69.63 \pm 23.1$ & $58.79 \pm 24.35$ & $81.46 \pm 24.82$ & $57.76 \pm 28.73$ \\
\hline$<6$ months & $19.03 \pm 8.95$ & $57.44 \pm 21.75$ & $55.58 \pm 25.64$ & $57.83 \pm 29.72$ & $65.72 \pm 24.29$ & $49.74 \pm 23.03$ & $84.79 \pm 20.43$ & $43.55 \pm 30.88$ \\
\hline \multicolumn{9}{|l|}{ Gender } \\
\hline Male & $23.23 \pm 6.88$ & $57.53 \pm 22.59$ & $55 \cdot 39 \pm 22.47$ & $65 \pm 25.12$ & $60.78 \pm 25.98$ & $52.2 \pm 20.36$ & $81.61 \pm 24.25$ & $47.54 \pm 27.28$ \\
\hline Female & $16.42 \pm 9.53$ & $66.23 \pm 22.27$ & $63.22 \pm 25.19$ & $67.07 \pm 27.9$ & $70.23 \pm 24$ & $58.44 \pm 24.73$ & $81.31 \pm 24.63$ & $55.57 \pm 30.59$ \\
\hline
\end{tabular}

social support showed lower levels of depression than those without. High perceived social support was strongly associated with a positive quality of life. The existing studies showed that the healthrelated quality of life of the patient with SLE was decreased and similar to patients with severe medical illness. ${ }^{14}$ In general, it was also found that the physical and mental health dimensions of quality of life appeared to be positively affected by the level of social support. Social support was inversely correlated with fatigue felt by the patient with SLE. These results confirmed the predictive role of social support that was benefited not only psychological health but also physical condition.

The value of the health-related quality of life domain in this study varied. Of all the domains, being a burden to others was the worst perceived by SLE patients. This domain measured the 
SLE patient's concern about being a burden to their environment. The low score in this domain indicated that they tended to judge themselves as a burden to those around them. In other words, there was a high level of concern about the effects of SLE impacting people in their environment.

To gain a deeper understanding of how bad or how good the quality of life of SLE patients is, we tried to compare it with the quality of life of the general population in Indonesia. No research directly studied SLE patients' quality of life with the general population in Indonesia. Still, we found a study about the Indonesian general population's quality of life. ${ }^{24}$ The previous study suggested that the Indonesian general population's quality of life (measured by WHOQOL-BREF) was $0.70-0.79 .{ }^{24}$ We found that SLE patients' quality of life scores were lower when compared to the general population. The comparison of quality of life (QoL) between SLE patients and the general population in Indonesia indicated that QoL of SLE patients was lower than the population without SLE, although to obtain more accurate results, the comparison of QoL between these two groups needs further research.

We also highlight the depression value in this research. It indicated that the depression experienced by the respondents was in the mild category. It also showed a large distribution or variation of data. These results confirmed previous studies which stated that SLE patients experienced mild to severe depression. From the distribution of values, it can be seen that there were respondents who had minimal depression scores, but there were also those who had severe depression scores. ${ }^{25}$ Groups of respondents with school/college students and unemployed status showed more severe depression scores than the employed and homemakers groups (data attached). Meanwhile, the group of SLE patients divorced, widowed, and single underwent more severe depression than the married group.

The value of depression also varied depending on the time of the last relapse. SLE patients who had their previous relapse three years ago showed minimal depression scores. In contrast, patients who had their previous relapse less than six months before data collection showed more severe depression scores in the moderate category. In the category of education, comorbidities, and duration of illness, there was no difference in the variation of depression levels in SLE patients.

The relationship between social support and mental and physical health was described in the literature by three main mechanisms: direct effects, buffering effects, and coping strategies. The primary effect hypothesis stated that social support was beneficial regardless of the level of stress experienced, indicating that more support is associated with better health. This idea is in line with the approach that includes social support as a component of the quality of life of SLE patients. ${ }^{26}$

The stress-buffering hypothesis predicted that social support acted as a protective factor against harmful effects of stress when individuals faced intense or persistent stressors. Stress has often been identified as an essential contributor to SLE disease activity. ${ }^{27}$

The coping strategies of SLE patients were believed to predict health outcomes. Regarding social support, several authors emphasized that living with SLE means dealing with several challenges, and many of these adaptive challenges require the help of others. For example, Kozora et al. ${ }^{28}$ stated that active coping strategies could be more adaptive in preventing depression.

We hypothesized that social support could positively influence psychological health by developing more active coping strategies than emotional coping. According to Lakey and Orehek, ${ }^{29}$ the mechanism of perceived social support and mental health can be explained by cognitive means. His research suggested that perceived social support worked like a cognitive schema by paying attention, assessing, and remembering support transactions. The experience of positive support transactions will form a positive schema about help and people who help. Perceived social support is a cognitive variable in personality that is relatively permanent; it is in the form of a collection of beliefs about the quality of a person's interpersonal/intimate relationships that will determine his interpretation and memory of social interactions. ${ }^{30}$

Perceived spiritual support is a form of perceived social support and is something that individuals believe in their relationship with God. ${ }^{11}$ To explain the effect of this support on depression and quality of life, we calculated the magnitude between perceived social support and spiritual support. The result showed a strong correlation between the two variables. It shows that once a cognitive scheme about individuals' relation with the environment (family, friend, and 
significant other) is interpreted as supportive, individuals tend to view other ties, including connection to God, as having a supportive nature.

According to Maton, ${ }^{11}$ spiritual support is a form of perceived social support. Maton ${ }^{11}$ concluded that individuals perceive the same elements of support in the context of their relationship with God as their relationships with people. Maton ${ }^{11}$ stated that spiritual support was perceived in the context of a relationship with God, emphasizing the perception and experience of love, presence, direction, and availability for themselves. Although Maton ${ }^{11}$ argued that spiritual support was a form of perceived social support, this study did find that spiritual support had a different effect on depression and quality of life as perceived social support has for these two variables.

As explained in the previous section, perceived social support works similar to the cognitive schema by paying attention, assessing, and remembering support transactions. To have confidence in a source of support when needed, one needs to have experience obtaining support from a particular source of support. The experience of positive support transactions will form a positive schema about help and people who help. Spiritual support has the exact nature of perceived social support: believing that God will provide support. Individuals need to have direct support transactions regarding the type of support and who supports them. Patients with SLE directly feel the help from their parents, friends, and significant others in their daily life. We hypothesized that direct support transactions seemed to be rarely experienced by individuals with their God. They generally felt support from God came through parents, friends, or significant others. The individual's cognitive schema will remember the helper as a figure who has helped them. Belief in God as a source of support has a weaker effect than a belief in figures who have directly supported them.

The limited research about perceived spiritual support becomes a theoretical gap and has implications for the inability of this study to explain the mechanism of the relationship between variables. This limitation opens the opportunities for further research on the relationship between belief in God's support and mental health, especially for people with a high religious culture such as Indonesia. The use of the BDI II as a measurement tool for chronic disease patients is still being debated, especially regarding fatigue items and sleep difficulties. Furthermore, online data collection (due to pandemic) made the target population less accessible-and the small number of respondents from Catholicism, Protestantism, and Hinduism was considered unrepresentative. The theoretical implication of this research is the empirical finding of the effect of spiritual support on individuals facing chronic stress. This variable was previously studied more in the condition of acute stress. The practical implication is that these findings will serve as the basis for stakeholders to consider perceived social and spiritual support variables in the depression treatment program for patients with SLE, which in the long run will improve their quality of life.

\section{Conclusions}

This study found that the health-related quality of life of SLE patients in Indonesia was affected by social and spiritual support and levels of depression. Social support (perceived social support) and spiritual support had a strong correlation and had different effects on depression and health-related quality of life. Social support directly affected depression and quality of life, while spiritual support affected the quality of life when patients with SLE were experiencing depression.

\section{Conflict of Interest}

There was no conflict of interest in this study.

\section{References}

1. Olesińska M, Saletra A. Quality of life in systemic lupus erythematosus and its measurement. Reumatologia. 2018;56(1):4554.

2. Division of Mental Health and Prevention of Substance Abuse World Health Organization. Program on mental health: WHOQOL user manual [Internet]. Geneva: World Health Organization; 1998 [2012 revision; cited 2021 April 15]. Available from: https://apps.who. int/iris/rest/bitstreams/110129/retrieve.

3. Macejová Z, Záriková M, Oetterová M. Systemic lupus erythematosus--disease impact on patients. Cent Eur J Public Health. 2013;21(3):171-3.

4. Mak A, Tang CS, Ho RC. Serum tumour 
necrosis factor-alpha is associated with poor health-related quality of life and depressive symptoms in patients with systemic lupus erythematosus. Lupus. 2013;22(3):254-61

5. Anindito B, Hidayat R, Koesnoe S, Dewiasty E. Validity and reliability of lupus quality of life questionnaire in patients with systemic lupus erythematosus in Indonesia. Indones $\mathrm{J}$ Rheumatol. 2016;8(2):38-44

6. Cleanthous S, Tyagi M, Isenberg DA, Newman SP. What do we know about self-reported fatigue in systemic lupus erythematosus? Lupus. 2012;21(5):465-76.

7. Anyfanti P, Gavriilaki E, Pyrpasopoulou A, Triantafyllou G, Triantafyllou A, Chatzimichailidou S, et al. Depression, anxiety, and quality of life in a large cohort of patients with rheumatic diseases: common, yet undertreated. Clin Rheumatol. 2016;35(3):733-9.

8. Hamilton JB, Galbraith KV, Best NC, Worthy VC, Moore LTCAD. African-American cancer survivors' use of religious beliefs to positively influence the utilization of cancer care. $\mathrm{J}$ Relig Health. 2015;54(5):1856-69.

9. Iskandarsyah A, de Klerk C, Suardi DR, Soemitro MP, Sadarjoen SS, Passchier J. Psychosocial and cultural reasons for delay in seeking help and nonadherence to treatment in Indonesian women with breast cancer: a qualitative study. Health Psychol. 2014;33(3):214-21.

10. Baron-Epel O, Friedman N, Lernau O. Validity of self-reported mammography in a multicultural population in Israel. Prev Med. 2008;46(6):489-91..

11. Maton KI.The stress-buffering role of spiritual support: cross-sectional and prospective investigations. JSSR. 1989;28(3):310-23.

12. Copertaro A, Bracci M, Manzella N, Barbaresi M, Copertaro B, Santarelli L. Low perceived social support is associated with $\mathrm{CD} 8+\mathrm{CD} 57+$ lymphocyte expansion and increased TNF- $\alpha$ levels. Biomed Res Int. 2014;2014:635784.

13. Lakey B, Orehek E, Hain KL, Van Vleet M. Enacted support's links to negative affect and perceived support are more consistent with theory when social influences are isolated from trait influences. Pers Soc Psychol Bull. 2010;36(1):132-42.

14. Mazzoni D, Cicognani E. Social support and health in patients with systemic lupus erythematosus: a literature review. Lupus.
2011;20(11):1117-25.

15. Uchino BN. Understanding the links between social support and physical health: a life-span perspective with emphasis on the separability of perceived and received support. Perspect Psychol Sci. 2009;4(3):236-55.

16. Bozo Ö, Tathan E, Yılmaz T. Does perceived social support buffer the negative effects of type C personality on quality of life of breast cancer patients? Soc Indic Res. 2014;119(2):791-801.

17. Miloseva L, Vukosavljevic-Gvozden T, Richter K, Milosev V, Niklewski G. Perceived social support as a moderator between negative life events and depression in adolescence: implications for prediction and targeted prevention. EPMA J. 2017;8(3):237-45.

18. Lakey B, Cronin A. Low social support and major depression: research, theory and methodological issues. In: Dobson KS, Dozois DJA, editors. Risk factors in depression. San Diego: Elsevier; 2008. p. 385-408.

19. Spilka B, Shaver P, Kirkpatrick LA. A general attribution theory for the psychology of religion. JSSR. 1985;24(1):1-20.

20. Cozby PC, Bates SC. Methods in behavioral research. $14^{\text {th }}$ Edition. New York: McGrawHill Education; 2020.

21. Laksmita OD, Chung MH, Liao YM, Chang PC. Multidimensional scale of perceived social support in Indonesian adolescent disaster survivors: a psychometric evaluation. PLoS One. 2020;15(3):e0229958.

22. Sargent AM. Moderation and mediation of the spirituality and subjective well-being relation [dissertation]. Fort Collins: Colorado State University; 2015. Available from: https:// mountainscholar.org/handle/10217/166907.

23. Ginting H, Näring G, van der Veld WM, Srisayekti W, Becker ES. Validating the Beck Depression Inventory-II in Indonesia's general population and coronary heart disease patients. Int $\mathrm{J}$ Clin Health Psychol. 2013;13(3):235-42.

24. Purba FD, Hunfeld JAM, Iskandarsyah A, Fitriana TS, Sadarjoen SS, Passchier $\mathrm{J}$, et al. Quality of life of the Indonesian general population: test-retest reliability and population norms of the EQ- $5 \mathrm{D}$ $5 \mathrm{~L}$ and WHOQOL-BREF. PLoS One. 2018;13(5):e0197098.

25. Beck AT, Alford BA. Depression: cause and treatment. $2^{\text {nd }}$ Edition. Philadelphia: 
University of Pennsylvania Press; 2009.

26. Yee CS, McElhone K, Teh LS, Gordon C. Assessment of disease activity and quality of life in systemic lupus erythematosus new aspects. Best Pract Res Clin Rheumatol. 2009;23(4):457-67.

27. Simard JF, Costenbader KH. What can epidemiology tell us about systemic lupus erythematosus? Int $\mathrm{J}$ Clin Pract. 2007;61(7):1170-80.

28. Kozora E, Ellison MC, Waxmonsky JA, Wamboldt FS, Patterson TL. Major life stress, coping styles, and social support in relation to psychological distress in patients with systemic lupus erythematosus. Lupus. 2005;14(5):363-72.

29. Lakey B, Orehek E. Relational regulation theory: a new approach to explain the link between perceived social support and mental health. Psychol Rev. 2011;118(3):482-95.

30. Lakey B, Cassady PB. Cognitive processes in perceived social support. J Pers Soc Psychol. 1990;59(2):337-43. 